Vol. 11, $n^{\circ} 2$ | 2007

Varia

\title{
Emmanuel Kreike, William Chester Jordan (eds), Corrupt histories. Studies in comparative history
} Rochester, N.Y., University of Rochester Press, 2006, 482 pp., ISBN 1-580-46173-5

Pieter Wagenaar

\section{CpenEdition}

\section{Journals}

Electronic version

URL: https://journals.openedition.org/chs/124

DOI: $10.4000 /$ chs. 124

ISSN: 1663-4837

\section{Publisher}

Librairie Droz

\section{Printed version}

Date of publication: 1 December 2007

Number of pages: 151-153

ISBN: 978-2-600-01224-9

ISSN: 1422-0857

Electronic reference

Pieter Wagenaar, "Emmanuel Kreike, William Chester Jordan (eds), Corrupt histories. Studies in comparative history", Crime, Histoire \& Sociétés / Crime, History \& Societies [Online], Vol. 11, n² | 2007, Online since 15 January 2009, connection on 22 March 2022. URL: http://journals.openedition.org/ chs/124 ; DOI: https://doi.org/10.4000/chs. 124

This text was automatically generated on 22 March 2022.

(C) Droz 


\title{
Emmanuel Kreike, William Chester Jordan (eds), Corrupt histories. Studies in comparative history
}

\author{
Rochester, N.Y., University of Rochester Press, 2006, 482 pp., ISBN
}

1-580-46173-5

Pieter Wagenaar

\section{REFERENCES}

Emmanuel Kreike, William Chester Jordan (eds), Corrupt histories. Studies in comparative history, Rochester, N.Y., University of Rochester Press, 2006, 482 pp., ISBN 1-580-46173-5

1 Corruption is an elusive concept, especially to historians. 'How should it be defined?', is the question bedeviling most scholars trying to study the phenomenon. Heidenheimer's work might be of help. After all, this scholar has developed a categorization of several types of corruption definitions. Corruption can be defined as breaking the rules pertaining to a certain office, it can be defined economically, and it can be defined as acting against general interest. Scott has drawn up a slightly different categorization: corruption is acting against the laws pertaining to it, or acting against what the public opinion deems integrity, or, again, acting against general interest.

Yet, both authors also point out what the drawbacks of these definitions are. If we define corruption as breaking the rules pertaining to a certain office, we use a modern, 'Weberian' definition of the phenomenon. Yet, Weberian bureaucracies hardly existed in the past, and are still lacking in many countries. What is more, breaking the rules can also be a practical necessity. All public functionaries do it, every now and then, without necessarily being corrupt. If we define corruption economically, we might be using a modern public-private dichotomy alien to past societies, and 'general interest definitions' of corruption fall short for the simple reason that there is no such thing as 'general interest'. There are only private interests claiming to be general interest. The 
same can be said about the public opinion. Societal groups differ hugely in their views on corruption, and these views are highly changeable. Legal definitions of corruption are probably the trickiest. Obviously, we cannot apply our laws to past societies, but looking to contemporary law for definitions of corruptions is just as dangerous. As it happens, law often follows practice, but at a distance, and also reflects the norms and values of only a part of society. Finally, not everything that is legal is considered to be ethical ${ }^{1}$.

Not long ago Michael Johnston has found a way out of these difficulties. He advocates a "neo-classical" approach to corruption: scholars should study the way the concept corruption is constructed, to find out how administrative and societal values have been fought over and have changed over time. Corruption scandals are often the moments when such struggles become visible, and when their outcomes are consolidated ${ }^{2}$. Following Johnston, we should not start with corruption definitions, we should investigate how corruption is defined and redefined.

4 How do the authors who have contributed to CorruptHistories deal with the many problems corruption poses to the historian? The volume consists of three parts: one on 'corrupt practices', one on 'corrupt discourses', and one on 'corrupting conjunctures'. In the first part Gambetta valiantly attempts to define corruption, and Johnston, who strives for a synergy between democracy, market and good governance, introduces four corrupt syndromes. The other authors in this part, however, practice a history of mentality. Will, who studies administration in late imperial China, describes how ideas on the necessity of sufficient remuneration for public functionaries were certainly not alien to Chinese administration, but how salaries remained meager nonetheless, making it necessary for administrators to supplement their income via unofficial means. Having to support an extended family, which, as a family, had also contributed to acquiring office, was another reason for corrupt practices. Doyle, who has studied France and Great-Britain between 1770-1850, describes how the Revolution put an end to venality in France, and how modern political parties proved to be an alternative to patronage in Britain. The root cause, in both cases, was the 'Strukturwandel der Öffentlichkeit'. Less analytical, but a very good read, is Goda's article on the way Hitler bribed his field officers.

5 The second part of the book focuses on discourse. Woodfine studies corruption rhetoric in Walpolean politics (England, first part of the $18^{\text {th }}$ century). In a world that did not know a strict public-private dichotomy, Walpole's regime slightly overdid things by systemizing corruption and organizing machine politics. Witwer, who has studied the teamsters union, makes an analysis of the change in meaning the word 'racketeering' underwent. The discrepancy between what the public opinion saw as racketeering, and the way in which the phenomenon was conceived on the shop floor, also grew steadily. Coulloudon describes twenty years of anti-corruption campaigns in Russia. Many forms of corruption were simply accepted in Soviet-Russia, as they were the only means to keep society going. The reasons behind the anti-corruption campaigns that did exist, were therefore often power-political. When Gorbachev introduced campaigns that were actually meant to combat corruption, his political opponents could therefore easily convince the public that once again the real objective was political infighting.

6 Surprisingly, many articles in the third part of the book also deal with discourse. Paravala provides a highly interesting analysis of the debate ( $18^{\text {th }}$ century) between Burke and Hastings on the questions whether English colonial administrators were 
allowed to partake in practices that were corrupt according to western norms, and whether administrators who did so and then returned to England, should be considered morally perverted. Simeon demonstrates how its corruption discourse is a function of India's specific route to modernity, and Adelman shows, using their corruption discourse, how Spain's and Portugal's rebellious colonies championed a return to the Ancien Régime rather than modernization. His article is a prime example of the neoclassical approach. Gregg's highly interesting article on international prostitution networks, fits the title of this part best, but is a bit of a red herring in the book as a whole.

7 Overall, the articles in Corrupt Histories navigate carefully around the many problems the concept of corruption poses to historians. It is surprising how 'Johnstonian' many of the contributions are. The book is a must for every historian looking for examples of how to tackle the subject.

\section{NOTES}

1. Heidenheimer, A. J., Terms, concepts and definitions: an introduction, in Heidenheimer, A. J., Johnston, M., Le Vine V. T. (eds), Political corruption: a handbook, New Brunswick, N.J., [etc.], 1989, 3-14; Johnston, M., The search for definitions: the vitality of politics and the issue of corruption, International social science journal, 1996, 149, 321-335; Theobald, R., Corruption, development and underdevelopment, Basingstoke [etc.], 1990 3-18; Werner, S. B., New directions in the study of administrative corruption, Public Administration Review, 1983, 43, 2, 146-154; Waquet,J.-C., Corruption. Ethics and Power in Florence,1600-1770, Pennsylvania, 1992, 1-18; Scott, J. C., Comparative political corruption,Englewood Cliffs, 1972, 3-4; Peters, J. G., Welch, S., Gradients of corruption in perceptions of American public life, in Heidenheimer e.a., Political corruption, 723-741, see 724-725; Gibbons, K. M., Toward an attitudinal definition of corruption, in Heidenheimer e.a., Political corruption, 165-171; Gardiner, J. A., Defining corruption, Corruption and Reform, 1993, 7, 111-124. 2. Johnston, The search for definitions, 331-334.

\section{AUTHORS}

PIETER WAGENAAR

Amsterdam, fp.wagenaar@fsw.vu.nl 